\title{
Transition from Enmity to 'Common Fate' Rhetoric: Water Issue in Turkish-Iraqi-Syrian Relations
}

\author{
Özden Zeynep Oktav ${ }^{*}$
}

\begin{abstract}
Starting from the fact that the water issues are the ones which challenge traditional security understanding, this article tries to analyze the basic reason(s) why Turkey, Syria and Iraq have not come to an agreement over the fair distribution of Euphrates-Tigris waters so far. The study presupposes that despite the rapprochement between Turkey, Iraq and Syria on the basis of 'common fate' rhetoric and good neighborhood strategy, water still exists as a dormant issue due to the security oriented priorities of the three countries. In addition, the ambitious plans of each country to divert the waters of the Euphrates-Tigris waters, and the lack of legally binding agreement are among the other reasons. The argument of the study is that the current problem of water between three countries is more than a resource problem; therefore, the GAP project is one of the concerns of the article. In addition, the article will focus on the fact that, unlike the 1990s, the three neighboring countries' previous negative rhetoric and attitude in dealing with their problems regarding water shortage have changed, to a large extent, into a positive one.
\end{abstract}

\section{Keywords}

Security, Common Fate, GAP, Cross-border Water Resources, Understanding of Model Partnership

*Özden Zeynep Oktav, PhD, is an associate professor in the Department of Political Science and International Relations, Yıldız Technical University, İstanbul, Turkey. 


\section{Introduction}

This article aims to explain that the water issue in EuphratesTigris basin has been a source of conflict due to the riparian governments' security based priorities, while water scarcity is an environmental problem and puts pressures on states to engage in greater interdependent relations and cooperation. Turkey's initiatives to ensure more cooperative relations in recent years resulted in a dramatic change of rhetoric of the three countries. However, the main motives lying behind the three countries' attitude change are not the protection of environment, water resources and enabling the local people to have a saying over their fate. On the contrary, the changing dynamics of the region and common threat perceptions have become effective in achievement of current rapprochement. In this context, the recent efforts of Ankara to build confidence and to ensure stability based on integrated relations are noteworthy because this will be a starting point to enhance cooperative relations on low politics issues in the future. The GAP project which was initiated to find solutions to low politics issues such as economic disparity, migration and unemployment is, therefore, a main concern of the article.

Most of the analysts have sought to explain the water issues from a state-centric perspective. However, the water issues are the ones which challenge traditional security understanding and they depict the complexity of the relations between the riparian countries which urge the cooperation over the use and protection of the river waters. This article presupposes that security oriented priorities are the basic reason why Turkey, Syria and Iraq have not come to an agreement over the fair distribution of EuphratesTigris waters so far. Put it differently, although sharing of Euphrates-Tigris waters is an environmental problem and it urges the three countries to engage in greater interdependent relations and cooperation, the lack of mutual trust, the primacy of political relations rather than respect for ecological systems, protection of environment shaped water policies of three countries especially during the 1990s. Despite the recent dramatic rapprochement between Turkey, Iraq and Syria on the basis of 'common fate' 
rhetoric and good neighborhood strategy, the study discusses that the water issue still exists to be a problem due to the ambitious plans of each countries to divert the waters of the Euphrates-Tigris waters, to their power based realist arguments and to the lack of legally binding agreement. The argument of the study is that the current problem of water between three countries is more than a resource problem. The GAP project, which depicts this argument best, is another concern of the article.

\section{Water Supply and Use}

The first priority for water use in Turkey is its energy need. The Southeastern Anatolia Project, (GAP) gained momentum at a time when Turkey was reaching a crisis; energy production was growing at 33 per cent but energy consumption skyrocketed 172 percent. While the project was originally scheduled for completion in 2010 and 1.7 million hectares of land would be irrigated and 27 billion $\mathrm{kWh}$ of hydraulic energy would be generated annually currently, fiscal constraints have intervened, and the deadline for completion of the scheme has been delayed until 2047.

The second priority is agricultural productivity so as to increase the variety of crops grown. With the increase of irrigable land, the Master Plan, prepared by the State Planning Organization, will promote agro-related manufacturing industries. Estimated employment in manufacturing is to increase between three and five fold. ${ }^{1}$ Third, and the most important priority of the project, is the fact that the GAP project represents an exemplary passage from simple water development to efficient water management.

Turkey is not alone in its desire to use the water of the river system as a basis for its industrial and agricultural development. Iraq and Syria also have had similar concerns because the Middle

${ }^{1}$ GAP ; the Master Plan: An Executive Summary, Ankara, State Planning Organization, 1989. 
East is rapidly becoming one of the least agriculturally selfsufficient regions in the world and governments are wary of dependency on food imports.

Syria also plans to divert a significant amount of water for agricultural development in the Euphrates valley so as to achieve "a relative food security" by 2010. One reason for pursuing a selfsufficiency strategy is the fact that Syria's oil reserves are small compared to other Middle Eastern countries and it has huge amounts of foreign debt. At the current rate of consumption, some 255,000 barrels per day, Syria's oil reserves will run dry in 25 years. When it comes to its food security, Syrian economy depends mostly on agriculture and big percentage of its population live in villages. Syria as well as Iraq followed a 'self-sufficiency' policy since 1950s and today "the vision of the ideal society, as depicted by the political leadership in both Syria and Iraq, includes agriculturally prosperous countryside. ${ }^{2}$ However, due to a number of reasons such as the rise in population growth rates that exceed the growth rates of agricultural production, irrational use of the limited natural resource base (land, water, forests and pasture), deterioration and contamination of the agricultural natural resources especially water, soil and natural pasture, lack of agricultural mechanization due to land fragmentation and the difficulty in expanding the invested areas, Syria still has challenges to achieve food security especially in rural areas. ${ }^{3}$

The Euphrates Valley Project is a conspicuous example with respect to understanding the Syrian policy of energy and irrigation, which resulted in failure to a great extent. The French envisaged the Euphrates Valley project in 1927. By 1963, the Syrian government decided to go ahead with the project with plans to build a large dam on the Euphrates River called the Euphrates-

\footnotetext{
${ }^{2}$ Ayşegül Kibaroğlu, "Building a Regime for the Waters of the Euphrates-Tigris River Basin”, Kluwer Law International, 2002, p. 15.

${ }^{3}$ Samira Al Zoughbi, "The State of Food Security: Recent Trends in Syria", Ministry of Agriculture and Agrarian Reform, National Agriculture Policy Center, Working Paper No: 17, 2006.
} 
Tabqa, renamed al-Thawra. The dam was completed in 1975, but its lofty targets were largely misplaced, partly due to overestimation of irrigation potential of the gypsiferous, crusty and erosion prone soils in the area, salinization caused by over-pumping and by the collapse of canals due to seepage. ${ }^{4}$ Another reason for failure, according to some analysts, was that Syria's drive to develop the Euphrates Valley had nothing to do with energy or agricultural production, but it was a clear method of the Ba'athist regime to extend their authority over and recast the social class. ${ }^{5}$ Apart from the above-mentioned factors, the loss of the Golan Heights to Israel and the increasing need of Syria for hydroelectric power, which is a cheap renewable energy resource, made Syria more dependent on the Euphrates-Tigris river system.

Iraq's situation is the worst of all. After American presence in Iraq, due to reduced domestic agricultural production, inflation, unemployment and a crumbling system of subsidized food distributions, big percentage of Iraqi people can't secure enough food. Iraq imports more than 80 percent of its food needs. ${ }^{6}$ According to Iraqi official figures, about 23 percent of Iraqis live below the poverty line. For example, at the water summit in Ankara, Iraqi Water Resources Minister Abdel Latif Jamal Rasheed stated that the situation was awful in terms of irrigation in Iraq, and even cutting the electricity production at the dams over the Tigris and Euphrates rivers and releasing their waters had not prevented the catastrophe, which has forced many Iraqis, especially those in the south, to leave their homeland. ${ }^{7}$ In addition

${ }^{4}$ Patrick Mac Quarrie, Water Security in the Middle East; Growing Conflict over Development in the Euphrates-Tigris Basin, MPhil Thesis, Dublin, International Peace Studies, Trinity College, 2004, p. 31.

5John Waterburry and Alan Richards, A Political Economy of the Middle East, Boulder, Westview Press, 1990, p. 32.

"Iraq: Food Insecurity on the Rise Say Officials", IRIN Middle East, 23 November 2009, <bttp:/ / mww.irinnews.org/Report.aspx?ReportId=86926>.

7 “Drought-Stricken Iraq Urges to Release More Water", Hürriyet Daily News and Economic Review, 03 September 2009,

$<$ bttp:/ / www. hurriyetdailynews.com/n.php?n=syria-iraq-in-throes-of-drought-urge-turkeyfor-more-water $>$. 
to the fact that the two thirds of the total land area of Iraq is a desert, decreasing amounts of rainfall in the last three years made Iraq highly dependent on the Euphrates and Tigris for irrigation water.

The three riparian countries currently seem determined to go ahead with their own development schemes with little consideration of the impact of their projects on the other states in the basin, with the exception of Iraq in the last few years due to its political disruption. The ambitious plans of the regional countries coupled with the lack of mutual trust and legally binding agreements make water a weapon or a threat rather than a tool for cooperation.

\section{Power Based Realist Arguments and Water Issue}

Because in the near future water demands of the riparians will surpass the amount of water supplied by the Euphrates, the disputes over water allocation are likely to worsen. Maximizing national interests and security so as to keep their power and stability has been the first priority of all three countries. Therefore as Lowi notes, because Syria, Iraq and Turkey failed to solve their high politics differences they could not cooperate on low politics. ${ }^{8}$

Some analysts see warfare and territorial acquisition as synonymous with water. This approach, in fact, ignores the water sharing agreements and the fact that water can be seen as a regional source similar to oil as a means to increase the economic interdependency between the riparian countries. For example, the GAP might have functioned as a tool for growing interdependence among the riparians due to its important impact on the other states via the river system. However, during the 1990s, the two neighboring as well as the Arab countries were alarmed by Ankara's initiatives such as improving its energy policy so as to

${ }^{8}$ Miriam R. Lowi, Water and Power: The Politics of a Scarce Resource in the Jordan River Basin, London, Cambridge University Press, 1993. 
reduce its dependency on expensive imports by producing at least 40 percent of its required energy from domestic hydroelectric sources. ${ }^{9}$ Furthermore, Ankara improved its military capability by firming its relations with Israel and abandoning its previous policy of balancing the Arabs with Israel. ${ }^{10}$ The dramatic change of policy towards the Arabs as well as its two neighboring countries enhanced their sense of vulnerability and made the power disparity between the parties more evident than ever. Ankara's reluctance to accept the Euphrates as an international river escalated the tension, and fostered the already existing distrust towards Turkey.

Here two points should be stressed: first, regardless of whether or not Turkey intends to dominate the Euphrates and Tigris rivers, the fact that Turkey was perceived by its neighbors as a threat to their own existence dictated the modus operandi for a long time. Therefore, from the Syrian and Iraqi perspective, Turkey's loss became their gain. Put differently, because of the perception that water is a finite resource, the GAP united Syria and Iraq and the discourse on water became defined in terms of conflict. Second, as Bengio and Özcan note, "the fear was that the Arab oil weapon would be overwhelmed by the Turkish water weapon." 11

From the Arabs' perspective, with the GAP Project, Turkey would emerge as the main source of grain in the region. Worst of all, Turkey, whose hand is on the tap, would hold Damocles' sword over their heads. For example, the Arabs' refusal of Turkey's gesture to bring drinking water from Anatolia down to the Arab peninsula through a pipeline to help the water poor

\footnotetext{
9İter Turan, "Water and Turkish Foreign Policy", The Future of Turkish Foreign Policy, eds. Martin G. Lenore and Dimitris Keridis, Cambridge, MIT Press, 2004, pp. 191-208.

${ }^{10}$ Ofra Bengio, The Turkish-Israeli Relationship: Changing Ties of Middle Eastern Outsiders, New York, Palgrave, 2004, pp. 71-103.

${ }^{11}$ Idem.
} 
countries depicts best the above-mentioned mutual distrust between the Turks and the Arabs. ${ }^{12}$

Much more serious, according to some analysts, is that the existing mutual distrust is a barrier for the formation of a network for data sharing and collecting among the riparian. With the Joint Technical Committee (JTC), proposed by Turkey during the 1960s as well as Three Stage Plan, ${ }^{13}$ Turkey aimed to facilitate the negotiation process and to create cooperative structures. However, neither the JTC nor the 'Three Stage Plan' fulfilled expectations of Iraq and Syria. This is not to say, of course, that Turkey's sole objective was to share data and knowledge. With those proposals, Ankara, for the most part, wished to determine the methods and procedures which would lead to a definition of the reasonable appropriate amount of water that each country would need from both rivers. Moreover, reaching a common terminology over the definition of the rivers to achieve a trilateral regime for determining the utilization of transboundary watercourses and to form a single transboundary river basin were other concerns of Ankara. Turkey, thus, would be able to cope with Syrian and Iraqi insistence on sharing of the international rivers; the Euphrates and Tigris.

Here, it should also be emphasized that with the efforts of the institutionalizing negotiation frame work, the priority of Turkey was to exclude third-party mediation or so-called third

\footnotetext{
${ }^{12}$ Murhaf Jouejati, "Water Politics As High Politics; the Case of Turkey and Syria", Reluctant Neighbour; Turkey's Role in the Middle East, ed. Henry J. Barkey, Washington D.C., US Institute of Peace Press, 1996, p. 143.

${ }^{13}$ Ali Çarkoğlu and Mine Eder, "Domestic Concerns and the Water Conflict over the Euphrates-Tigris River Basin", Middle Eastern Studies, Vol. 37, No. 1 (2001), p. 56. Joint Technical Committee meetings were held to provide and share data concerning the riparian countries' needs for present and future projects to prepare a statement of main principles and procedures in order to reach an agreement on water rights. "Three Stage Plan" for Optimum Equitable Research and Reasonable Utilization of the Transboundary Watercourses of the Tigris-Euphrates Basin aimed to allocate water resources based on the systematic assessment of water needs for irrigation of all parties.
} 
party intervention which Ankara had complained of during the construction of the Keban and Karakaya dams. According to Ankara, the donors' intervention was solely in favor of protecting the rights of the downstream riparian and gave slight recognition of Turkish rights to develop and use the river system. ${ }^{14}$

It is noteworthy that the three countries' joint dependency on the Euphrates-Tigris brings about questioning of the traditional security understanding based solely on military might and diplomacy because the economic, environmental and ecological approach to security requires a basic change in security understanding so that the existing system can survive. In this context, it can be said that with the GAP project, Turkey has shown its enthusiasm to change its traditional security understanding by adopting new solutions to its existing economic, environmental and ecological problems in Southeastern Anatolia. The GAP project has shifted over the years from an infrastructure development project into a project that coordinates social, cultural, economic and environmental efforts and this is, in fact, in parallel with the changes in global thinking about development.

This approach urges states to take the local interests into consideration so as to enable the local people to have a saying over their own fate. However, currently Ankara has been severely criticized on the ground that it pays lip service to the needs of the local people. Many analysts argue that there is a gap between the states' intentions and the needs on the local level. Put it differently, so far dams mainly produce electricity, the provision of water for irrigation has fallen far behind. Moreover, it is alleged that the works have tended to promote the development of the regions of the West, not the impoverished East. ${ }^{15}$

\footnotetext{
${ }^{14}$ Ayşegül Kibaroğlu and Olcay Ünver, "An Institutional Framework for Facilitating Cooperation in the Euphrates-Tigris River Basin", International Negotiation: A Journal of Theory and Practice, Vol. 5, No. 2 (2000), pp. 311-330.

${ }^{15}$ Altan Tan, "Erdoğan'in Kredisi Yüksek" Yeni Şafak, 26 November 2007. <bttp://yenisafak.com.tr/Roportaj/Default.aspx?t=26.11.2007 \&i=83933>;

“GAP ‘Kürt Sorununu’ Çözmeye Yeter mi?” Star, 09 June 2008.
} 
The Ilisu dam ${ }^{16}$ is a conspicuous example with respect to understanding Turkey's state-centered policies disregarding the needs of local people, the Kurds. ${ }^{17}$ Apart from the strongly worded protests concerning Turkey's violation of human rights and protection of environment the Ilisu dam has a direct bearing on bilateral relations between Iraq, Syria, and Turkey enhancing Turkey's superiority over its two neighbors because of Ankara's refusal to debate the issue at the interstate level, as it saw this as a principle of sovereignty. ${ }^{18}$ This has made it evident that Turkey has been determined to construct new dams not only on the Euphrates but also on its sister river Tigris at the expanse of its good neighborhood relations because the Ilisu dam would reduce the amount of fresh water, impairing the diluting capacity to purify the wastewater flowing from the region's major cities (Baghdad feared its flow to be contaminated by agricultural chemicals and pesticides); and finally it would also inflame the debates about riparian water rights and the lack of no agreed principles governing international rivers.

\section{Recent Developments}

The American military presence in Iraq made water rights less important and enhanced Turkey's value in the eyes of Syria. Put bluntly, the fear was that the military presence of the occupation of Iraq would open Syria to American encroachments, or at least place it at the mercy of Washington, at a time when Syria felt encircled by the two allies of the United States, Israel and

\footnotetext{
16"Turkey, Syria and Iraq in Water Crisis Summit", <http://www.cnn.com/2009/WORLD/meast/09/03/turkey.water.shortage>, (access date : 03 September 2009).

${ }^{17}$ Behrooz Morvaridi, "Resettlement, Rights to Development and the Ilisu Dam, Turkey”, Development and Change, Vol. 35, No. 4 (2000), pp. 719-741.

18“Ilisu Dam Project in for Hard Times Despite Government Plans", Turkish Politics in Action, 26 July 2009, < bttp:/ / turkishpoliticsinaction.blogspot.com/2009/07/ilsu-dam-project-in-for-hardtimes.htm〉.
} 
Turkey. What one needs to emphasize at this point, however, is that once they flared up, both Syria and Iraq had attempted to give the water problem an all-Arab coloring and to turn it into conflicts between Turkey and the entire Arab world. But currently, Damascus, who has lost its Arab partners, has felt threatened by the spillover effect of the Iraqi invasion, and therefore, it has tried to build up a closer relationship with Turkey. This rapprochement on every aspect of relations, such as military, economic and developing water resources, is not only related to Syria's sense of vulnerability but also to Turkey's concern about the US's designs regarding the foundation of a Kurdish statehood in the Middle East.

For now it is unknown how Iraq's present conflict might affect a unified Iraqi voice at the negotiation table. But when it comes to Syria, the upgrading of Turkey's relations with Syria, especially after Öcalan's departure from Syria and Hafez Asad's death, had a direct and positive impact on the water issue. The basic reason for the amelioration of relations concerning the acute water problem is security oriented. In the face of the probability of Iraqi fragmentation so as to clear the way for an independent Kurdish state on Turkey's southern border, Ankara preferred to adopt closer relations with Syria which had already been improved to a large extent after the signing of the Adana Agreement in 1998. ${ }^{19}$ In December 2004, Turkish Prime Minister R. T. Erdoğan visited Damascus, where Erdoğan and his Syrian counterpart, Muhammed Naji Otri, signed a free trade agreement, which was under negotiation for several years. During the visit, Otri said: 'Other problems are forgotten,' apparently referring to other key obstacles to full normalization of relations, such as the sharing of the Euphrates River. It is also noteworthy that Bashar Asad, during his visit to Turkey, put emphasis on the fact that the two countries moved together from an atmosphere of distrust to one

\footnotetext{
${ }^{19}$ Özden Zeynep Oktav, "The October 1998 Crisis: The Change of Heart of Turkish Foreign Policy Towards Syria?”, CEMOTI Chaiers D'Etudes Sur La Mediterranee Orientale Et Le Monde Turco-Iranien, 2001, p. 146.
} 
of trust, which was completely due to both countries' opposition to the US-led invasion and occupation of Iraq. ${ }^{20}$

Soon after Hafez Asad's death, Syria, because of the political reasons mentioned above, felt the necessity of solving its acute water problem with Turkey and a Joint Communiqué was signed between the General Organization for Land Development (GOLD) of the Irrigation Ministry of Syria, and the GAP Regional Development Administration (GAP RDA) on August 23, 2001. ${ }^{21}$ The agreement envisioned the cooperation of the two sides in such areas as training, mission studies, technology exchanges, and the conduction of joint projects. The twofold aim of both countries was that this agreement and its subsequent implementation protocol (2002) would provide sustainable utilization of the region's land and water resources, and finally it would deal with water management within a larger picture of overall socio-economic development and integration of the underdeveloped regions in Turkey and Syria.

The question that needs our concern is the following: what are the incentives for both countries to initiate cooperative relations in solving water-related problems whereas, only few years ago they were at the brink of war? Main motive for Syria is to end its isolation in international arena. Syria's existing anxieties regarding a scenario of a pincer movement from the north (Turkey) and the south (Israel) by the two strongest armies in the region were further exacerbated by the military presence of the United States in Iraq. Here the reasoning is that only with a strong Turkey back in the region was there a chance to counterbalance Israel and the American military presence in the region. When it comes to Turkey, the US invasion of Iraq meant strengthening the bridges of the Iraqi Kurds with those living in south-eastern Anatolia hence Ankara strongly believed that the foundation of a

${ }^{20}$ K. Gajendra Singh,. "A New Age for Turkey-Syria Relations", Al-Jazeerah, 14 April 2005; People's Daily Online, 06 January 2004.

21 "Joint Irrigation Project with Syria", Bianet News in English, 26 August 2002, <bttp:// bianet.org/english/agriculture/12744-joint-irrigation-project-with-syria >. 
Kurdish statehood in the northern Iraq was the ultimate goal of Washington.

However, the recent dramatic changes such as election of a Democrat politician, Obama to American presidency, Washington's firm decision to withdraw the American troops from Iraq by the end of 2011 eased the way for Turkey to follow a proactive foreign policy in the Middle East so as to change Ankara's traditional policy of seeing the Kurdistan Regional Government (KRG) as an external enemy sheltering the PKK guerrillas. The visit of the Foreign Minister Davutoğlu and Trade Minister Zafer Çağlayan to Erbil, capital city of the KRG is a ground breaking event with respect to understanding Ankara's determination to initiate a new age in the region. ${ }^{22}$ In this context, it can be said that Ankara's previous threat perceptions regarding American support to the foundation of an independent Kurdish state have faded away. Moreover, Ankara's initiatives such as signing High-Level Strategic Cooperation Council Agreement with Syria and High-Level Strategic Cooperation Council with Iraq (see website of the Turkish Foreign Ministry) are noteworthy because Turkish officials stressed that the main motto is common destiny, history and future so as to build the future together. ${ }^{23}$ Despite Mutual visits by high-level officials and to the fact that Turkey's contribution to the reconstruction of Iraq increased the trust, and although it seems that security concerns were replaced by opportunities for cooperation, water still remains as a thorny issue among the three neighboring countries due to several reasons. One is about Turkey's reluctance to enter into long-term binding international agreements; another is Ankara's determination not to

\footnotetext{
22“"Etle Tirnak Gibiyiz”, Milliyet, 01 November 2009.

23"Turkey Syria Sign Strategic Deal Lift Visa". < bttp:// wnw.turkishny.com/ en/english-news/15588-turkey-syria-sign-strategic-deal-liftvisa.html>, (access date: 17 September 2009).

"Davutoğlu: Irak'la Su Meselesine Ortak Kader Olarak Bakıyoruz", Turkish Journal, 11 August 2009.
} 
exceed the determined amount on the ground that Turkey is not a water rich country. ${ }^{24}$

For example, during the water summit in Ankara, as an answer to Iraqi Water Minister Latif Rashid's complaint that Turkey had broken its promise to increase water flows down the Euphrates River, Energy and Natural Resources Minister Y1ld1z mentioned that while Turkey provided Syria and Iraq 500 cubic meters of water a second, central and eastern Turkey received only 350 cubic meters/second of water in $2009 .{ }^{25}$ In addition, Ankara, noting that Turkey released water from Atatürk Dam on the Euphrates to its neighbors at the cost of risking its own share of energy to meet the demands of Iraq and Syria, emphasized that water is an opportunity for international cooperation rather than conflict. However, since it is strongly believed that Turkey's GAP project and the Ilisu dam would reduce the waters of the Tigris River by $47 \%$ and deprive the northern Iraqi city of Mosul of $50 \%$ of its summer water requirements, official circles in Iraq and Syria are rather pessimistic about international cooperation. ${ }^{26}$ Here the issue is that, as many analysts argue, water is perceived as a matter of hegemony and for example, the Ilisu dam will let the Turkish government control the Tigris River and this is a mechanism to control the water in the region which would undermine Syria and Iraq's access to water. ${ }^{27}$

At the same time, however, unlike the 1990s, the three neighboring countries' previous negative rhetoric and attitude in dealing with their problems regarding water shortage changed to a

24“Turkey Says More Water for Iraq and Syria is Unlikely", Syria Comment, 4 September 2009. <http://joshualandis.com/blog/?p=3959>.

${ }^{25}$ Idem.

${ }^{26}$ For example, in the face of Iraqi Water Minister Latif Rashid's complaint that Turkey had broken its promise to increase water flows down the Euphrates River, Energy Minister of Turkey, Yildız said: "We are not pleased with the talks in the Iraqi parliament either. Turkey is being criticized in an unfair way although it sticks to its commitments on water issues."

${ }^{27}$ Patrick Wrigley, "Dam Dispute Strains Turkey-Iraq Ties", Asia Times, 02 October 2009. 
large extent into positive one. For example, although the water summit was held at a time when political tension stemming from Iraqi accusations that Syria was harboring terrorists had been on the agenda, the Syrian and Iraqi officials did not cut the links on negotiation; they came together at water summit in Ankara. This is, to a large extent, due to Ankara's shuttle diplomacy talks in Damascus and Baghdad in order to establish peace and stability in the Middle East in accordance with Davutoğlu's policy of zero problems with neighbors. ${ }^{28}$ In this context, Turkey prefers to treat water resources not as individual rivers or cross-border water resources, but as basins. ${ }^{29}$ This policy urges the three neighboring countries to be open to dialogue which currently is applied successfully. For example, the three countries' decision to form a water institute so as to exchange developments in water technology for the renovation of irrigation and portable water systems is noteworthy. ${ }^{30}$

In a nutshell, the recent developments openly showed that the three neighboring countries proved their ultimate preference for closer cooperation in water issue. Above all, the worsening water shortage in Iraq which affects environment, drinking water and agriculture is the main reason lying behind Baghdad's insistence on a permanent agreement. Ankara, on the other hand, prefers to solve water issue by means of bilateral talks rather than multilateral water sharing agreements on the ground that Turkey and Iraq share a common fate and if they spread 'understanding of model partnership', "the Middle East will no longer remain as the region of crisis and conflicts. It will turn into a very important basin where joint interests and mechanisms of joint political

${ }^{28}$ Ahmet Davutoğlu, Stratejik Derinlik; Türkiye'nin Uluslararası Konumu, İstanbul, Küre Yayınlar1, 2001, p. 401.

${ }^{29}$ Bülent Keneş, "World Water Forum and Need for 'Pax Water' around Turkey" Todays Zaman, 16 March 2009.

30"Drought-Stricken Iraq Urges to Release More Water", Hürriyet Daily News and Economic Review, $03 \quad$ September 2009, $<$ ttp:/ / www. hurriyetdailynews.com/ n.php? $n=$ syria-iraq-in-throes-of-drought-urge-turkeyfor-more-water>. 
dialogue and security are realized." 31 The same rhetoric, 'common fate, common history, common future' (el kader el müsterek, ettarib el müsterek, el müstakbel el müsterek) is also used in relations with Syria. ${ }^{32}$

The questions that need concern us are to what extent will the above-mentioned rhetoric on the trilateral Turkey-Iraq-Syria relations be sustainable in the future? Is there any possibility that Syria and Iraq would make a volte face in case of any change in political conjuncture of the region in the future? Leaving aside futurology, two points should be stressed: first, the major driving force behind the above-mentioned improving relations based on open dialogue regarding water issue is security and diplomacy oriented one. Protection of environment and enabling the local people living in the basin to have a saying over water-related decisions are not on the agenda of the three countries.

Second, although Ankara gives the message that Turkey is equal partner of Iraq and Syria, currently, Turkey, due to its relatively developed economy, democracy and to its western political culture, is the leading country which produces solutions to water problems. ${ }^{33}$ Therefore, it benefits from the existing dynamics in the region. In the long run, this political culture of Ankara which urge conciliation, interwoven relations and stress the common historical, cultural heritage will probably make low politics issues top priority of the three neighboring countries.

31“Iraq, Turkey Want to Integrate Economies", Son Gazetesi, 18 September 2009, < < <ttp:// wmw.songazetesi.com/iraq-turkey-want-to-integrate-economiesi1931.html .

32“"Savaşın Eşiğinden Sınırsız Dostluğa”, Zaman, 14 October 2009.

33“'Turkey's Budding Relations with Syria and Iraq", Turkish Weekly, 02 November 2009, <http:// www.turkishweekly.net/op-ed/2579/turkey-39-s-buddingrelations-with-syria-and-iraq.htm〉. 


\section{Conclusion}

The Middle East the water resources are viewed as finite and water is an issue which can be defined in terms of conflict, as states have to battle in zero-sum terms to ensure their share of water and their survival. Therefore, the GAP project was perceived as a major blow to Syrian as well as Iraqi water interests, and during the 1990s, Syria gave support for the extremist PKK (Kurdish Workers' Party) in its insurgency against Turkey as a trump card to prevent Ankara from blocking the water.

One explanation of the above-mentioned hostility is related to the nature of relations and leadership adopted by the two neighboring countries in the basin during the 1990s. When compared to the present situation, the leaders of both Syria and Iraq; Hafez Asad, Saddam Hussein were more authoritarian leaders who saw water as a tool of conflict rather than conciliation. On the other hand, Turkey, seeing the two neighboring countries as interfering in Turkish internal affairs; 'coveting' Turkish lands and water; inciting the Kurds and supporting the 'terrorist' acts against Turkey, sought the ways of being a well equipped military power in the region throughout the 1990s.

Some analysts argue that the leaders of democracies prefer non-violent measures to resolve crises, whether or not opponents are democratic. Much more important, institutions of democracy socially construct individuals who prefer to use non-violent means of dispute resolutions. In other words, humans are different in a democracy. ${ }^{34}$ Here the issue of crucial importance is that analysts put emphasis on individuals in a democracy. Indeed, the importance of full engagement of citizens other than state actors in solving the problems is most evident in environmental issues such as water scarcity because the fact that half the population of the

\footnotetext{
${ }^{34}$ Jr. Karl DeRouen and Shaun Goldfinch, "Democracies Prefer to Negotiate: Institutionalized Democracy, Diversion, and Statecraft during International Crises", New Directions For International Relations, eds. Alex Mintz and Bruce Russett, Oxford, Lexington Books, 2005, pp. 158-159.
} 
world depends on the water and land resources of transboundary river basins make cooperative relations between states over the use and protection of rivers a key component in addressing water development needs all over the world. However, within high politics of international water negotiations the concerns of local people and need to involve the public in the process of arriving at basin management strategies and agreements are often overlooked. ${ }^{35}$ Without public participation and involvement of civil society partners at all level, it would be impossible to achieve sustainable cooperation and to solve the problems regarding world's international basins so as to ensure stability, security, democracy and human rights.

Although after the Cold War the spread of democracy and the opening up of global politics brought about the increased influence of civil society, the internal dynamics as well as conjuncture of the Middle East, put differently, high politics problems hindered Syria and Iraq from adopting global thinking about development. The global thinking urges the state actors to accept the logic of public administration in environmental decision making, and the benefits of decentralized management.

When it comes to Turkey, the GAP has been viewed by Turkish officials as a project to put an end to the disparity among regions of Turkey in social and economic development in addition to solving problems such as migration and unemployment. Much more important according to Ankara, because the economic disparity was the sole reason of the instability in the region, the GAP project would enhance the concept of citizenship of the Republic of Turkey and it would put an end to the separatist feelings among the local people, the Kurds in the region.

\footnotetext{
${ }^{35}$ Curtin Fiona, "Emerging Trends in Water Resources Conflict Prevention: Public Purticipation and Role of Civil Society", Water Development and Cooperation-Comperative Perspective: Euphrates-Tigris and Southern Africa, ed. Lars Wirkus, Bonn, International Center for Conversion, 2006.
} 
In his speech, the Prime Minister Erdoğan explained "the GAP action plan" or "the center of attraction plan" 36 by which the cities like Gaziantep and Şanliurfa would be transformed into centers of attraction and thus people of the region would be kept in the area. However, in the same speech, the prime minister harshly criticized local municipalities of the region, a majority of whose mayors are from the pro-Kurdish Democratic Society Party (DTP). ${ }^{37}$ This illustrates and even epitomizes the duality and ambivalence prevailing in Ankara's policies towards the region. This ambivalence is due to the fact that the government's efforts to complete the project increased along with its fears of a growing threat from the local municipalities which were strongly believed to be "separatists" by the governmental cadres. Put differently, despite a huge investment on the GAP project, today the polarization on the axis of Kurdish-Turkish nationalism has increased more than it ever had in the past. This is mainly due to the failure of the Turkish officials to understand the close link between human rights, protection of environment and managing transboundary rivers which urge the strong involvement of people.

Water scarcity is an environmental problem and puts pressures on states to engage in greater international cooperation. From a different angle, since water scarcity is a special kind of threat which is not a threat to states but to mankind as a whole, many international relations scholars argue that environmental issues require 'thinking globally and acting locally'. ${ }^{38}$ This is one of the best known Green political slogans which automatically challenge the existence of centralized, sovereign states-system in the Middle East. Therefore, unless the three riparian countries give up parochialism and adopt the idea that they have fundamental obligations on the rest of the world so as to perceive water scarcity as a resource problem having a direct link with human and

\footnotetext{
36“South Eastern Anatolian Project Action Plan, 2008-2012", <bttp:/ / www.gap.gov.tr/Turkish/Genel/ eylem812.pdf>.

37“Erdoğan GAP Eylem Planını Açıkladı”, Hürriyet, 27 May 2008.

${ }^{38}$ Matthew Paterson, "Green Politics", Theories of International Relations, eds. Andrew Linklater, et.al., New York, Palgrave, 2005, p. 244.
} 
environmental needs, it can be said that the current amelioration between Turkey, Iraq and Syria regarding the utilization of Euphrates-Tigris waters will come to an end at any time when the three countries' common threat perception basically based on high political priorities change. 